\title{
Development Initiatives and Changing Social Stratification: The Case of Western Odisha, India
}

\author{
Balgovind Baboo \\ Senior Academic Consultant, Odisha State Open University, Sambalpur, Odisha, India \\ Email: baboo.bg@gmail.com
}

How to cite this paper: Baboo, B. (2017) Development Initiatives and Changing Social Stratification: The Case of Western Odisha, India. Open Journal of Social Sciences, 5, 114-121.

https://doi.org/10.4236/jss.2017.58009

Received: June 21, 2017

Accepted: August 5, 2017

Published: August 8, 2017

Copyright $\odot 2017$ by author and Scientific Research Publishing Inc. This work is licensed under the Creative Commons Attribution International License (CC BY 4.0).

http://creativecommons.org/licenses/by/4.0/ (c) (i) Open Access

\begin{abstract}
Social stratification refers to the hierarchical arrangement of individual and groups in society according to certain important attributes which are decided by the concerned society. Development by itself is an evolutionary process but of late this process is initiated by governments, NGOs, professionals, media and sometimes stray individuals. In this paper we have tried to understand the impact of state-sponsored developmental initiatives in the form of formal legislations, industrial urbanization and agricultural modernization on different segments of the populace in western Odisha, India. Besides the use of published sources and folklores, the study has used data collected first hand from six different types of villages to underhand the changing pattern of stratification in a spatio-temporal context. It was found that despite the communication revolution and post-independent development initiatives the cultural rigidity is very much there and there has not been much of structural differentiation as well.
\end{abstract}

\section{Keywords}

Social Stratification, Development, Caste, Tribe, Opportunities, Religion

\section{Conceptual Clarification}

Development may be defined as a process of change, which may be planned or unplanned, manifested in different domains of material and non-material aspects of nature and culture. Taking a balanced view development would refer to growth with distributive justice. However, development is not a uniform process in different parts of the world. Some pockets may be more developed than others in material terms whereas it may be the opposite in non-material terms. The no- 
tion of development is a complex, controversial and contested one [1]. Development may also be determined in terms of the location of a population or social group in a particular locality. People living in the hinterland, forest and hills might be less developed as compared to people living in the plains and fertile river basins. On the other hand, within a particular geographical territory some people may be more developed than others. This can be evident intra-nationally and internationally. In a changing situation, e.g. the introduction of a new technology or opportunities the participating population behaves differently and the consequential result is differential development.

Social stratification refers to hierarchical ordering of social groups according to certain well defined attributes. This is different from differentiation and ranking which are more of bio-physical in nature [2]. Class, status and power are universally recognized as the basis of social stratification but the criteria for ordering position as higher or lower are not universal and not a permanent one. In Europe people might be arranged according to their economic position, in India according to one's caste and in some other places according to the religious sects and clans .In urban India one's occupation and profession might be the basis of stratification whereas in the rural area one's caste and familial position might be taken seriously whereas in the tribal areas ones lineage might be important. To the extent that measurement of superior or inferior social position is not purely based on objective criteria, social stratification becomes a complex phenomenon and it is more intriguing to relate it with development which is equally a value loaded term. However, it is interesting for a social scientist to delve into such a situation. In this paper we would examine the relationship between social stratification and development in India.

Physically as well as socially India is a heterogeneous and diversified country: in terms of racial features, ethnicity, religious groups, topography and agro-climatic conditions. We go along with the deterministic school of Human Geography to say that climate, topography and other aspects of physical environment shape the social attitudes of human individuals or groups [3]. People in the plains may be more goal oriented, materialistic, clever, extrovert, educated and quick in decision making. On the other hand, people in the hinterland/periphery or those who live in the hills and forests might have the opposite cultural traits. While there are differentiation in terms of race, sex, regions, age and all that which lead to unequal development that are partly inbuilt in the system, differences in development due to stratification seems to be more pervasive.

Social scientists, for a long time, have tried to understand the difference in development in terms of rural and urban sectors [4] or in terms of some opportunities like irrigation, industry, etc. [5]. For generalizing at an all India level we must try to understand three sectors-tribal/primitive, peasant/multi-caste and industrial urban. These three sectors are not mutually exclusive but rather overlapping. This is because the pristinity of any of these sectors cannot be maintained in the era of globalization. Similarly within the social groups like castes 
and tribes there have been considerable changes as also in their mutual interaction. Normally a tribe is a self-contained, self-sufficient and isolated group with a dialect, cultural distinctiveness and strong community feeling but without much of hierarchy [6]. The chieftain, headman or the tribal priest is respected and enjoys certain privileges and authority. After Independence the Scheduled Tribes (henceforth STs), constituting about 8.6 percent of the Indian population, are enjoying certain facilities as also the Scheduled Castes (henceforth SCs) constituting some $16.6 \%$ of the population. On the other hand, the Hindus $(80 \%$ of the Indian population) as a religious group subsuming the different castes and certain sects as well, have a highly differentiated social order with elaborate cultural practices There are some 3000 castes and 25,000 sub-castes in India, each related to a specific occupation. There are more than 1100 Scheduled Castes and more than 740 Scheduled Tribes. Such diversity itself leads to a complex social situation. The essence of caste is hierarchy, endogamy, close system, purity and pollution and caste specific occupation. Caste Panchayats (meetings) are conducted to maintain the purity of caste practices and to decide important issues including aberrational practices. Castes have cooperation amongst them in the domain of jajmani relation (patron-client relationship) which is practiced in a contiguous geographical area [7].

\section{The Historical Backdrops}

The colonial masters who ruled over India for more than two centuries did not touch much of the religio-cultural practices of the tribes and castes in the initial phases although they found them quite absurd. Later on they tried to reform some of these after spreading Missionary activities in the tribal pockets (providing health and education facilities) and amongst the educated caste groups in the urban areas [8]. People among the castes and the tribes, who took benefits of these offer improved their social and economic status compared to rest of the population. Social mobility during this period was also related to peoples' physical mobility and a change of attitude. The British policies on land tenure, forest policies, introduction of irrigation in some pockets of the country, as also commercial crops and the vending of liquor differentiated the relatively homogeneous caste societies and tribal communities [9].

After Independence three factors have been very important for large scale change in India: formal legislations, agricultural modernization and industrial-urbanization. Formal legislations have all-India ramification and are usually applicable to all social groups with minor modifications. India being largely an agriculture-dependent country modernization process in the form of farm mechanization, controlled and perennial supply of irrigation, soft loans from formal financial institutions and the use of inputs like chemical fertilizers and pesticides have made remarkable changes and fragmented the society at large. Similarly expansion in industrial-urban activities, introduction of formal institutions replacing the informal ones, sharp division of labour, professional and occupa- 
tional groups and rapid transit system and communication have led to development which are not uniform and not unilinear.

\section{The Objectives}

Our objective, in this paper, is to understand the relation between social stratification and development in western Odisha, India. More specifically we are interested to understand the impact of government initiated developmental activities in the form of formal legislations, industrial-urbanization and agricultural modernization on three distinct groups of people-the SCs, the STs and the general castes. The basic assumption behind the governmental initiative was that the long standing social and economic inequality in society could be reduced by state intervention. We have tried to examine whether this objective has been realized especially in the domain of tribe, caste and class.

\section{The Field of Study and Techniques of Data Collection}

Keeping the different sectors and the introduction of irrigation as a major variable in the agriculture based society; we selected six different types of villages of Sambalpur district in western Odisha to observe the impact of the post-colonial initiatives or rather the impact of planned developmental programmes on the existing stratification pattern. These six villages were: tribal dry village (TDV), tribal wet village (TWV), peasant dry village (PDV), peasant wet village (PWV), suburban dry village (SDV) and suburban wet village (SWV). We also took a round of the prominent towns of the area: administrative (Sambalpur), commercial (Bargarh), educational (Burla), and industrial (Hirakud). Being a sociologist from western Odisha and having experienced and observed the social scenario from close quarters over long-term, I selected a few key informants of different age groups in each of the villages and towns who gave me an idea of the nature of social stratification that evolved historically in the selected places and the intervening factors which shaped the present one. We also examined the data from the Village and Town Directories conducted by the Census of India for different years, the District Gazetteers starting with the colonial times and some folksongs of the area.

\section{Data Analysis}

During the pre-colonial period there was hardly any stratification among the tribals-such as Sahara, Kandha, Gond, Binjhal, etc., of Sambalpur district. The colonial policies of fixing taxes and tariffs on liquor led these tribals, who brew their own liquor earlier, to buy it from the licensed vendors; led them to produce cash crops, mortgage/sell their land which pauperized most of them. The tenurial policies on land and forest also led to the embryonic form of class formation among them [10]. Some of them also became attached and casual labourers [11].

The most visible forms of development in western Odisha in the post-independent period was the construction of the Rourkela Steel Plant, the Indian 
Aluminum Company at Hirakud, the Orient Paper Mill at Brajaraj Nagar, cement factories at Bargarh and Rajgangpur and the refractory at Belpahad. The construction of the Hirakud dam, the largest earthen dam in the world, across river Mahanadi was done for flood control, generation of electricity for domestic consumption and industrial growth and year round irrigation (especially for paddy cultivation); the establishment of an Engineering College, a Medical College and a University all in Burla changed the higher education scenario in this area [12]. The bridge across river Mahanadi and $\mathrm{Ib}$ and the railway connection between Howrah and Nagpur via Jharsuguda and Sambalpur opened up the entire area for communication and commerce [13]. These small towns attracted some of the STs from the hinterland who earlier eked out a living from hunting, food gathering and a bit of settled agriculture.

While some of the tribals who got regular salary in the government and private sectors because of their education and bare training skill the casual labourers underwent miseries, drunkenness and social evils. The unity, collective sentiments and mutual exchange system got eroded. Some of the general castes like the Kultas, Sundhis, Telis, etc and even the Muslims have penetrated into the tribal dry villages as traders and moneylenders and have settled therein and in some cases have alienated the tribals of their ancestral properties. In the irrigated belt the tribals gradually got alienated of their land and became dependent on the doles provided by the government. Education and access to communication helped the trbals in the towns to enter the job market and prosper a little. But overall they are physically less mobile and lead a happy-go-lucky life. They are less mobile than the SCs as well [14].

The SCs in all the villages and overall in the district are no better off than the STs. In some places there is conflict between the SCs and STs especially on the issue of land rights. Unlike the STs the SCs had some jajmani relation with the rest of the castes in the villages and they performed specific functions on special occasions as well. The Gandas were basically farm labourers, were not allowed inside the house of the other castes for domestic work, rarely did some petty business and were overall poor and illiterate. The Ghasias were village scavengers/sweepers and sometimes worked as messengers for the local landlords. They were also farm labourers and depended on the rice/paddy given by other caste groups for the menial activities. The Chamars, the lowest caste among the SCs, used to lift the dead animals and cattle in the village. They used to eat the meat of the dead cows/bullocks and sold the hides; sometimes used the hide for covering musical instruments or prepare string out of it for agricultural use. Sometimes some of these caste groups had sparse distribution in a locality and since they monopolized over some services, which others are not allowed to do, it cannot simply be generalized that the lower the status of a caste the higher its exploitation liabilities and vice-versa [15]. Despite the declaration by the Great Mahatma Gandhi to shun untouchability and call these people as Harijan (the people of God) and despite several developmental initiatives by the government of India and Odisha the condition of these people is still very depressing. Several 
protective discrimination measures, privileges, facilities, and incentives in the realm of education, political representation, housing, soft loans and waivers and reservation in jobs there were hardly any individual or household from the studied villages ,both from the SCs and STS, except in the suburban villages, who were visible or upwardly mobile.

Access to cheaper higher education, government offices, transport and communication, year round employment and several opportunities in the suburban dry and wet villages made some of the SCs and STs visible. Looking at a macro level when the SCs and STs in some locality and some segments have prospered, they have least bothered to develop the rest of their fellow beings. In this way a creamy layer is being formed among the SCs and STs who go on perpetuating/reproducing their cultural capital [16]. When we see the SCs and STs as a group who were historically disadvantaged and who are being protected by the State, the other castes especially the industrious and studious ones are feeling discriminated. They feel that government is just wasting money on them who are not deserving, not hardworking, who are wasting the opportunities and who are simply surviving on the doles. In some area this is leading to caste conflict more so when some of these people go for conversion to get economic benefits from other religious groups.

Among the general caste groups in the non-irrigated area there has not been much change in the conventional hierarchy: the dominant castes [17] are still dominating but the nature of this dominance has changed primarily because of the introduction of the adult franchise where numerical superiority becomes important. Improvement in the transport and communication system has enabled the poor people from the lower castes also to move out of the village to look for higher education and job opportunities. This has relieved them from both social and economic bondage. However, their imitation of the upper caste cultural practices and consumerism (partly contributed by television) is keeping them perpetually indebted. Different type of governmental doles in the form of loan waivers, old-age pension, and below-poverty line facilities, housing facilities, etc. are making these people complacent and lazy. As a result labour productivity is also decreasing. At the same time seasonal migration to irrigated areas as well as to cities outside Odisha is very much visible. The jajmani relation of the sevayats (service provider castes) and the rest of the population is virtually no more in vogue but cooperation amongst the people for social and ritual functions are still visible to some extent.

In the irrigated area there is practice of chemical and commercial agriculture emphasizing on farm mechanization and production of mono-cropped high yielding variety of paddy in the Hirakud Command area. Hence there is no cooperation among the peasants (now farmers), for mutual exchange of labour and livestock, which helped them for a long time during crisis. Mutual support in cash or kind is also very little prevalent and everybody is dependent on the formal financial agencies. Whereas poor people are not in a position to utilize the full facility from these agencies, the rich section utilizes this loan and their ance- 
stral property for usurious money lending and business in the construction and agricultural sector. Some of the Brahmins (uppermost caste) are now absentee landlords and they have this nefarious practice.

When we compare the six studied villages we find that the cultural rigidity is the highest in the TDV and the least in the SWV. There is more of structural perpetuation in the dry villages and differentiation in the wet villages. Caste as an important attribute of social stratification is losing its weight but not getting eradicated completely despite the impact of higher education, physical mobility, media and mobile phone. For example, there is little prevalence of inter-caste or inter-tribal marriage and in case of it's happening the concerned families are socially ostracized or looked down upon. Untouchability is not completely wiped out and the Harijans are not allowed to enter the temples. Similarly, despite the existence of stringent laws against usury and the prevalence of so many formal financial agencies and the Self Help Groups, informal money lending is rampant. Superficial Changes in infrastructural facilities, basic amenities and pro-poor activities are visible in all the villages but the polarization process is almost simultaneous. The upper caste, land-owning families with higher education who have access to and control over resources are not only prospering but nullifying the developmental initiatives by the government. The bureaucracy has not been of much help to the poor section. As widely believed agrarian prosperity is a myth in the Hirakud command area. More and more farmers are leaving agriculture as they no more consider it an economic proposition; many others cling to it as there is no other alternative. More than 3600 farmers, including 474 women, have committed suicide between 1999 and 2013 [18] because of poor harvest, crop loss and indebtedness. That is, the present form of chemical farming has not been sustainable of late and there is some sort of crisis in agriculture, even at the all India level. A false sense of freedom is enjoyed by the labourers who are moving out of the villages to work in distant towns but not saving much as they incur several unexpected expenditure in the new locality and more often live through a system of borrowing-repaying-borrowing. Depletion of natural resources and lack of cooperation amongst the rural populace is ushering into a peculiar pattern of social stratification which should arouse the social scientists to introspect seriously as to where do we go from here.

\section{Conclusion}

A section of the historians have all along accused colonialism as the source of all ills in the Indian society without realizing that Indian society was already a fragmented one along several social indicators. There was no unity in the diversities of India, as is widely believed. The jajmani system, the mutual exchange of labour and livestock, the traditional social and ritual functions and the religious epics sustained the mass to overcome many crises. Colonial policies and the associated reforms necessarily divided the society further. But post-independent efforts in planning and the later proliferation of globalization have made the ex- 
isting social stratification much more complex and may not be as desired by those in power. Our effort of linking the macro policies and their interplay in the six types of villages is a case in point. This reminds us of a comparative social historian who explained the social crisis in India in terms of mega society, multiple codes and social blank [19].

\section{References}

[1] Garada, R. (2015) Interrogating the Development Discourses: A Sociological Introspection. IOSR Journal of Humanities and Social Science, 20, 58-67. www.iosrjournals.org

[2] Grusky, D.B. and Ann, A.T. (1992) Social Stratification. The Encyclopedia of Sociology. Macmillan Publishing Company, 1955-1970.

[3] Diamond, J. (1997) Guns, Germs and Steel: The Fates of Human Societies. W.W. Norton and Company.

[4] Sorokin, P.A. and Zimmerman, C.C. (1929) Principles of Rural-Urban Sociology. Henry Holt, New York, 16.

[5] Das Harish, C. (1978) Resources and Responses in Two Orissan Villages: The Influence of the New State Capital, 1950-1970. Punthi Pustak, Calcutta.

[6] Beteille, A. (1975) Six Essays in Comparative Sociology. Oxford University Press, Delhi.

[7] Kolenda, P.M. (1963) Towards a Model of the Hindu Jajmani System. Human Organization, 22, 11-31. https://doi.org/10.17730/humo.22.1.x01162046g995q1j

[8] Baboo, B. (1979) The Naga National Movement: An Analysis. Third World Unity, No. 15-17, 41-62.

[9] Raut, S.K. (1979) Commercialization of Agriculture in Orissa during the Late 19th Century. M. Phil Dissertation, JNU, Delhi.

[10] Pathy, J. (1976) Political Economy of Kandha Land. Man in India, 56.

[11] Thapar, R. and Siddiqieds, M.H. Eds. (1979) Chotanagpur: The Pre-Colonial and Colonial Situation in Trends in Ethnic Group Relations in Asia and Oceania. UNESCO, Paris.

[12] Baboo, B. (1989) The Economic History of Sambalpur District 1849-1947: An Introduction. Social Scientist, No. 181-182, 26-34.

[13] Senapati, N. and Mahanti, B. (1971) Orissa District Gazetteer (Sambalpur). Orissa Govt. Press, Cuttack.

[14] O’Malley, L.S.S. (1909) Bengal District Gazetteer, Sambalpur.

[15] Baboo, B. (1986) Cognition and Structure: Explaining the Exploitation of an Untouchable Caste in Orissa. The Eastern Anthropologist, 39, 187-195.

[16] Baboo, B. (2017) Rethinking Reservation Policy: The Case of the Scheduled Castes and the Scheduled Tribes in Orissa. American Journal of Social Sciences, 5. http://www.openscienceonline.com

[17] Oommen, T.K. (1970) The Concept of Dominant Caste: Some Queries. Contributions to Indian Sociology, 4, 73-83. https://doi.org/10.1177/006996677000400105

[18] Nath Pradip, K. and Hemprabha, C. (2016) Political Economy of Farmers' Suicide: A Case of Western Odisha. Mainstream, 54, 23-29.

[19] Saberwal, S. (1985) Modelling the Crisis: Megasociety, Multiple Codes, and Social Blanks. Economic and Political Weekly, 20, 202-211. 
Submit or recommend next manuscript to SCIRP and we will provide best service for you:

Accepting pre-submission inquiries through Email, Facebook, LinkedIn, Twitter, etc. A wide selection of journals (inclusive of 9 subjects, more than 200 journals)

Providing 24-hour high-quality service

User-friendly online submission system

Fair and swift peer-review system

Efficient typesetting and proofreading procedure

Display of the result of downloads and visits, as well as the number of cited articles Maximum dissemination of your research work

Submit your manuscript at: http://papersubmission.scirp.org/

Or contact jss@scirp.org 